\title{
ANALISIS FAKTOR YANG BERHUBUNGAN DENGAN PARTISIPASI SUAMI DALAM MENJAGA KESEHATAN KEHAMILAN DI WILAYAH KERJA PUSKESMAS GADING REJO KABUPATEN PRINGSEWU
}

\author{
Aprina $^{1}$, Nurul Aziza ${ }^{2}$ \\ ${ }^{1}$ Poltekkes Tanjungkarang, ${ }^{2}$ Pascasarjana STIKES Mitra Lampung \\ Email: aprinamurhan@yahoo.co.id
}

\begin{abstract}
Factor Analysis Related to Husband's Participation During Pregnancy in Gading Rejo Health Center, Pringsewu. Husband's role during pregnancy is very important. Participation and support of husband were affect psychosocial aspects. Maternity ladies must be accompanied by a trusted person and make her comfortable during childbirth (Bobak, 2005). This study design was analytical survey approach Cross Sectional. Population were all a husband whose wife was pregnant trimester III in working area Gading Rejo Health Centre, Distric Pringsewu, in Januari to June 2016, as much as 273 peoples. Total sampel were 121 peoples. The research instruments were used questionnaires. Multivariate analyzes were used multiple regression logistic. There was a relationship of knowledge (p-value $=0,002$ OR=3.688), attitude ( $p$ value $=0,030 \quad \mathrm{OR}=2521)$, education level $(\mathrm{p}$-value=0,020OR=2.815), employment ( $\mathrm{p}$ value $=0,007 \mathrm{OR}=4351$ ), and income ( $\mathrm{p}$-value $=0,000 \mathrm{OR}=6.981)$ with the participation of husband. The variable income was the most dominant variable related to the husband's participation in the health of wife's pregnancy ( $\mathrm{p}$-value $=0.000 \mathrm{OR}=7142$ ).
\end{abstract}

Keywords:Husband, Participation, Health, Pregnancy

\begin{abstract}
Abstrak: Analisis FaktoryangBerhubungan dengan Partisipasi Suamidalam Menjaga Kesehatan Kehamilan di Wilayah Kerja Puskesmas Gading Rejo Kabupaten Pringsewu. Partisipasi dan dukungan suami yang diterima sangat mempengaruhi aspek psikologisnya, maka dalam hal ini, ibu yang bersalin harus ditemani oleh orang yang ia percaya dan membuatnya merasa nyaman agar persalinan berjalan normal. (Bobak, 2005). Tujuan penelitian diketahui faktor faktor yang berhubungan dengan partisipasi suami dalam menjaga kesehatan kehamilan di wilayah kerja Puskesmas Gading Rejo Kabupaten Pringsewu Tahun 2016. Jenis penelitian Kuantitatif, rancangan penelitian analitik pendekatan cross sectional.Populasi seluruh suami yang isterinya sedang hamil trimester III di wilayah kerja Puskesmas Gading Rejo Kabupaten Pringsewu pada bulan Januari sampai dengan Juni 2016 sebanyak 273 orang, sampel 121 orang menggunakan metode Probability Sampling. Instrument penelitian menggunakan kuesioner.Analisis Multivariat yang digunakan adalah multiple regression logistic. Ada hubungan pengetahuan dengan partisipasi suami ( $p$-value $=0,002)$. Ada hubungan sikap dengan partisipasi suami $(p$-value $=0,030)$. Ada hubungan tingkat pendidikan dengan partisipasi suami ( $p$-value $=0,020)$. Ada hubungan pekerjaan dengan partisipasi suami ( $p$-value $=0,007)$. Ada hubungan pendapatan dengan partisipasi suami $(p$ value $=0,000)$. Variabel pendapatan merupakan variabel yang paling dominan berhubungan dengan partisipasi suami dalam menjaga kesehatan kehamilan istri ( $p$-value $=0,000$; OR $=7.142$ ). Saran untuk pelayanan kesehatan lebih tingkatkan upaya sosialisasi partisipasi suami seperti Penerimaan Bantuan Iuran (PBI) BPJS kepada suami, dan mensosialisasikan jenis jenis makanan yang dibutuhkan ibu hamil melalui demonstrasi langsung.
\end{abstract}

Kata kunci: Partisipasi, Suami, Kesehatan, Kehamilan

Angka Kematian Ibu (AKI) di Indonesia masih jauh lebih tinggi dari pada negara Asia Tenggara lain nya. Hal ini dapat terjadi karena adanya kelompok kehamilan beresiko. Sementara itu berdasarkan Millenium Development Goal's (MDGs) 2015, Kementrian Kesehatan Republik Indonesia menargetkan 2/3 angka kematian balita dalam kurun waktu 1990 dan 2015. Survey
Demografi dan Kesehatan Indonesia (SDKI) Tahun 2012, AKI (yang berkaitan dengan dengan kehamilan, persalinan, dan nifas) sebesar 359 per 100.000 kelahiran hidup. Angka ini masih cukup jauh dari target yang harus dicapai pada tahun 2015. Penyebab kasus kematian ibu di Provinsi Lampung Tahun 2013 disebabkan oleh pendarahan sebanyak 47 kasus, eklampsia 
sebanyak 46 kasus, infeksi sebanyak 9 kasus, partus lama sebanyak 1 kasus, aborsi sebanyak 1 kasus dan lain lain sebanyak 54 kasus (Dinkes Provinsi Lampung 2014).

Salah satu upaya yang dilakukan pemerintah untuk menurunkan angka kematian dan kesakitan ibu adalah dengan memperluas layanan Antenatal Care (ANC). Cakupan K1 dan K4 di Provinsi Lampung cenderung berfluktuatif naik turun jika dibandingkan dengan target pertahun nya cakupan K1 dan cakupan K4 belum mencapai target. Jika distribusi K1 dan K4 per kabupaten/ kota maka cakupan K1 terbesar yaitu Bandar Lampung, Pesisir Barat, Pesawaran, dan Lampung Selatan. Sedangkan cakupan terendah yaitu Way Kanan (Dinkes Provinsi Lampung Tahun 2014).

Menurut Dinas Kesehatan Provinsi Lampung, target kunjungan K1 dan K4 tahun 2014 adalah 95\%, sedangkan cakupan kunjungan ibu hamil k4 untuk Kabupaten Pringsewu pada tahun 2014 hanya mencapai 94\%. Pringsewu mendapat peringkat ke 6 tertinggi kasus AKI dari 15 kabupaten di Provinsi Lampung. Dan Kecamatan Gading Rejo mempunyai riwayat AKI yang fluktuatif (KIA Puskesmas Gading Rejo) dan dipilih Puskesmas Gading Rejo karena setiap tahunnya ada kematian ibu bersalin. Sejak tahun 1999 sampai 2015 kasus kematian ibu mengalami kenaikan yang berarti. Penyebab kematian ibu secara langsung adalah perdarahan pasca persalinan, infeksi dan eklamsi.

Upaya pemerintah dalam rangka menurunkan AKI di Indonesia pada tahun 2000 dengan merancangkan Making Pregnancy Safer (MPS) yang merupakan strategi sektor kesehatan secara terfokus pada pendekatan dan perencanaan yang sistematis dan terpadu. Salah satu dari stategi MPS adalah memberdayakan dan melibatkan peran serta perempuan, suami dan masyarakat oleh pemerintah. Ketidaktahuan suami dalam mengenal komplikasi, keterlambatan mengenal bahaya dirumah, keterlambatan fasilitas pelayanan cukup berakibat fatal. Pada umumnya suami tidak mengetahui adanya tanda bahaya di rumah, walaupun suami atau anggota keluarga mengetahui adanya keluhan yang dirasakan oleh ibu hamil. Selama ANC suaminya tidak mengetahui jadwal ANC, sehingga suami terkadang mengantar istrinya periksa hamil jika kebetulan ia berada dirumah. Disamping itu suami tidak pernah bertanya atau mencari informasi kepada bidan, teman atau orang tua perihal kehamilan istrinya. Suami juga tidak mengetahui tanda bahaya yang terjadi di rumah dan kondisi ibu hamil serta resiko yang dapat muncul secara tiba-tiba, sebagai akibat dari faktor usia, jarak kehamilan, jumlah anak dan beban kerja (BKKBN, 2008).

Penelitian Mahlida. (2012) Hubungan Dukungan Suami Terhadap Tingkat Kepatuhan Pemeriksaan Kehamilan Di Puskesmas Simo Mulyo Surabaya didapatkan hasil p-value 0,000 berarti bahwa ada hubungan dukungan suami dengan tingkat kepatuhan pemeriksaan kehamilan. Puskesmas Gading rejo sendiri menurut pengamatan bidan setempat ibu hamil yang memeriksakan kehamilan hanya diantar oleh kerabat atau saudara, adapun yang memereksakan kehamilan nya sendirian, ada pula yang di temani suami nya tetapi suaminya tidak sampai masuk kedalam ruang pemeriksaan untuk mengetahui perkembangan isteri dan janin nya. Tujuan penelitian diketahui faktor yang berhubungan dengan partisipasi suami dalam menjaga kesehatan kehamilan di wilayah kerja Puskesmas Gading Rejo Kabupaten Pringsewu Tahun 2016.

\section{METODE PENELITIAN}

Jenis penelitian kuantitatif. Penelitian dilakukan di Puskesmas Gading Rejo Kabupaten Pringsewu. Waktu penelitian bulan Maret sampai dengan Juni 2016. Populasi seluruh suami yang isterinya sedang hamil trimester III di wilayah kerja Puskesmas Gading Rejo Kabupaten Pringsewu pada bulan Januari sampai dengan Juni 2016 sebanyak 273 orang dengan sampel berjumlah 121 responden. Teknik sampel menggunakan Probability sampling. Peneliti menggunakan Sampling Acak Sederhana (Simple Random Sampling) (Notoatmodjo, 2010). Cara pengambilan sampel pada penelitian ini adalah dengan menggunakan buku kohort yang ada di puskesmas, poskesedes, posyandu dan bidan desa. Alat ukur yang digunakan dalam penelitian ini adalah kuesioner. Kuesioner yang dibuat sesuai kerangka konsep penelitian berdasarkan dengan teori yang berkaitan dengan variabel variabel yang diteliti. Kuesioner memuat pertanyaan pertanyaan dari Predispossing Factor, Enabling Factor, dan Reinforcing Factor dan juga variabel dependen dan Independen. Analisis data dilakukan dengan univariat menggunakan distribusi frekuensi, analisa bivariat dengan menggunakan uji chi square. Analisis Multivariat digunakan adalah multiple regression logistik (Hastono, 2007). 


\section{HASIL}

\section{A. ANALISIS UNIVARIAT}

Berdasarkan tabel diketahui bahwa partisipasi suami dalam menjaga kesehatan kehamilan istri lebih tinggi pada kategori kurang berpartisipasi sebesar 75 orang $(62 \%)$, pengetahuan suami tentang dalam menjaga kesehatan kehamilan istri lebih tinggi pada kategori kurang berpartisipasi sebesar 82 orang (68\%), sikap suami dalam menjaga kesehatan kehamilan istri lebih tinggi pada kategori kurang negatif sebesar 79 orang (65\%), tingkat pendidikan suami lebih tinggi pada kategori rendah sebesar 87 orang (72\%), pekerjaan suami lebih tinggi pada kategori bekerja sebesar 90 orang $(74 \%)$, Berdasarkan tabel 5.6 diatas distribusi pendapatan suami lebih tinggi pada kategori rendah sebesar 68 orang (56\%), jumlah anak lebih tinggi pada kategori <3 sebesar 93 orang $(77 \%)$, budaya lebih tinggi pada kategori tidak menerima sebesar 80 orang (66\%), dukungan keluarga lebih tinggi pada kategori tidak mendukung sebesar 94 orang (78\%), dukungan petugas kesehatan lebih tinggi pada kategori mendukung sebesar 78 orang $(64.5 \%)$, akses kepelayanan lebih tinggi pada kategori dekat sebesar 70 orang $(58 \%)$.
Tabel 1. Hasil Analisis Univariat

\begin{tabular}{lcc}
\hline \multicolumn{1}{c}{ Variabel } & Frek & \% \\
\hline Partisipasi Suami & & \\
Berpartisipasi & 46 & 38 \\
Kurang Berpartisipasi & 75 & 62 \\
\hline Pengetahuan & & \\
Baik & 32 & 39 \\
Kurang Baik & 68 & 82 \\
\hline Sikap & & \\
Positif & 42 & 32 \\
Negatif & 79 & 68 \\
\hline Pendidikan & & \\
Tinggi & 87 & 72 \\
Rendah & 34 & 28 \\
\hline Pekerjaan & & \\
Bekerja & 90 & 74 \\
Tidak & 31 & 26 \\
\hline Pendapatan & & \\
Tinggi & 53 & 44 \\
Rendah & 68 & 56 \\
\hline Jumlah Anak & & \\
<3 & 93 & 77 \\
$\geq 3$ & 28 & 23 \\
\hline Budaya & & \\
Menerima & 41 & 34 \\
Tidak & 80 & 66 \\
\hline Dukungan Keluarga & & \\
Mendukung & 27 & 22 \\
Tidak & 94 & 78 \\
\hline Dukungan Petugas Kesehatan & & \\
Mendukung & 78 & 64,5 \\
Tidak & 43 & 35,5 \\
\hline Akses Ke Pelayanan & & \\
Dekat & 70 & 58 \\
Jauh & 51 & 42 \\
\hline & & \\
\hline & & \\
\hline
\end{tabular}

\section{B. ANALISIS BIVARIAT}

Tabel 2. Hubungan Pengetahuan Dengan Partisipasi Suami Dalam Menjaga Kesehatan Kehamilan

\begin{tabular}{|c|c|c|c|c|c|c|c|c|}
\hline \multirow{3}{*}{ Pengetahuan } & \multicolumn{4}{|c|}{ Partisipasi suami } & \multirow{3}{*}{$\mathbf{n}$} & \multirow{3}{*}{$\%$} & \multirow{3}{*}{ p-value } & \multirow{3}{*}{$\begin{array}{c}\text { OR } \\
\text { CI 95\% }\end{array}$} \\
\hline & \multicolumn{2}{|c|}{$\begin{array}{c}\text { Kurang } \\
\text { Berpartisipasi } \\
\end{array}$} & \multicolumn{2}{|c|}{ Berpartisipasi } & & & & \\
\hline & $\mathbf{n}$ & $\%$ & $\mathbf{n}$ & $\%$ & & & & \\
\hline Kurang baik & 59 & 72 & 23 & 28 & 82 & 100 & 0,002 & 3.688 \\
\hline Baik & 16 & 41 & 23 & 59 & 39 & 100 & & $(1.658-8.203)$ \\
\hline Total & 75 & 62 & 46 & 38 & 121 & 100 & & \\
\hline
\end{tabular}

Berdasarkan tabel di atas hasil uji statistik didapat $p$-value $=0,002$, yang berarti ada hubungan pengetahuan dengan partisipasi suami dalam menjaga kesehatan kehamilan istri, Nilai OR didapat 3.688 yang dimaknai bahwa responden dengan pengetahuan kategori baik memiliki peluang 3.688 kali lebih besar berpartisipasi dalam menjaga kesehatan kehamilan istri dibandingkan responden dengan pengetahuan kategori baik. 
Tabel 3. Hubungan Sikap Dengan Partisipasi Suami Dalam Menjaga Kesehatan Kehamilan Partisipasi suami

\begin{tabular}{|c|c|c|c|c|c|c|c|c|}
\hline \multirow{3}{*}{ Sikap } & & \multirow{3}{*}{$\mathbf{n}$} & \multirow{3}{*}{$\%$} & \multirow{3}{*}{ p-value } & \multirow{3}{*}{$\begin{array}{c}\text { OR } \\
\text { CI 95\% }\end{array}$} \\
\hline & \multicolumn{2}{|c|}{$\begin{array}{c}\text { Kurang } \\
\text { Berpartisipasi }\end{array}$} & \multicolumn{2}{|c|}{ Berpartisipasi } & & & & \\
\hline & $\mathbf{n}$ & $\%$ & $\mathbf{n}$ & $\%$ & & & & \\
\hline Negatif & 55 & 70 & 24 & 30 & 79 & 100 & 0,030 & 2.521 \\
\hline Positif & 20 & 48 & 22 & 52 & 42 & 100 & & $(1.164-5.457)$ \\
\hline Total & 75 & 62 & 46 & 38 & 121 & 100 & & \\
\hline
\end{tabular}

Berdasarkan tabel di atas hasil uji statistik didapat $p$-value $=0,030$, yang berarti ada hubungan sikap dengan partisipasi suami dalam menjaga kesehatan kehamilan istri, Nilai OR didapat 2.521 yang dimaknai bahwa responden dengan sikap kategori positif memiliki peluang 2.521 kali lebih besar berpartisipasi dalam menjaga kesehatan kehamilan istri dibandingkan responden dengan sikap negatif.

Tabel 4. Hubungan Tingkat Pendidikan dengan Partisipasi Suami dalam Menjaga Kesehatan

\begin{tabular}{|c|c|c|c|c|c|c|c|c|}
\hline \multirow{3}{*}{$\begin{array}{c}\text { Tingkat } \\
\text { pendidikan }\end{array}$} & \multicolumn{4}{|c|}{ Partisipasi Suami } & \multirow{3}{*}{$\mathbf{n}$} & \multirow{3}{*}{$\%$} & \multirow{3}{*}{ p-value } & \multirow{3}{*}{$\begin{array}{c}\text { OR } \\
\text { CI 95\% }\end{array}$} \\
\hline & \multicolumn{2}{|c|}{ Kurang Baik } & \multicolumn{2}{|c|}{ Baik } & & & & \\
\hline & $\mathbf{n}$ & $\%$ & $\mathbf{n}$ & $\%$ & & & & \\
\hline Rendah & 60 & 69 & 27 & 31 & 87 & 100 & 0,020 & 2.815 \\
\hline Tinggi & 15 & 44 & 19 & 56 & 34 & 100 & & \\
\hline Total & 75 & 62 & 46 & 38 & 121 & 100 & & $(1.246-6.361)$ \\
\hline
\end{tabular}

Berdasarkan tabel di atas hasil uji statistik didapat $p$-value $=0,020$, yang berarti ada hubungan tingkat pendidikan dengan partisipasi suami dalam menjaga kesehatan kehamilan istri, Nilai OR didapat 2.815 yang dimaknai bahwa responden dengan pendidikan kategori tinggi memiliki peluang 2.815 kali lebih besar berpartisipasi dalam menjaga kesehatan kehamilan istri dibandingkan responden dengan pendidikan kategori rendah.

Tabel 5. Hubungan Pekerjaan dengan Partisipasi Suami dalam Menjaga Kesehatan Kehamilan

\begin{tabular}{|c|c|c|c|c|c|c|c|c|}
\hline \multirow{3}{*}{ Pekerjaan } & \multicolumn{4}{|c|}{ Partisipasi suami } & \multirow{3}{*}{$\mathbf{n}$} & \multirow{3}{*}{$\%$} & \multirow{3}{*}{$p$-value } & \multirow{3}{*}{$\begin{array}{c}\text { OR } \\
\text { CI 95\% }\end{array}$} \\
\hline & \multicolumn{2}{|c|}{ Kurang baik } & \multicolumn{2}{|c|}{ Baik } & & & & \\
\hline & $\mathbf{n}$ & $\%$ & $\mathbf{n}$ & $\%$ & & & & \\
\hline Tidak Bekerja & 26 & 84 & 5 & 16 & 31 & 100 & 0,007 & 4.351 \\
\hline Bekerja & 49 & 54 & 41 & 46 & 90 & 100 & & $(4.351-12.349)$ \\
\hline Total & 75 & 62 & 46 & 38 & 121 & 100 & & \\
\hline
\end{tabular}

Berdasarkan tabel di atas hasil uji statistik didapat $p$-value $=0,007$, yang berarti ada hubungan pekerjaan dengan partisipasi suami dalam menjaga kesehatan kehamilan istri, Nilai OR didapat 4.351 yang dimaknai bahwa responden yang tidak bekerja memiliki peluang 4.351 kali lebih besar berpartisipasi dalam menjaga kesehatan kehamilan istri dibandingkan responden yang tidak bekerja.

Tabel 6. Hubungan Pendapatan dengan Partisipasi Suami dalam Menjaga Kesehatan Kehamilan

\begin{tabular}{|c|c|c|c|c|c|c|c|c|}
\hline \multirow{3}{*}{ Pendapatan } & \multicolumn{4}{|c|}{$\begin{array}{l}\text { Partisipasi suami } \\
\end{array}$} & \multirow{3}{*}{$\mathbf{n}$} & \multirow{3}{*}{$\%$} & \multirow{3}{*}{$p$-value } & \multirow{3}{*}{$\begin{array}{c}\text { OR } \\
\text { CI 95\% }\end{array}$} \\
\hline & \multicolumn{2}{|c|}{ Kurang baik } & \multicolumn{2}{|c|}{ Baik } & & & & \\
\hline & $\mathbf{n}$ & $\%$ & n & $\%$ & & & & \\
\hline Rendah & 55 & 81 & 13 & 19 & 68 & 100 & 0,000 & 6.981 \\
\hline Tinggi & 20 & 38 & 33 & 62 & 53 & 100 & & $(3.072-15.864)$ \\
\hline Total & 75 & 62 & 46 & 38 & 121 & 100 & & \\
\hline
\end{tabular}

Berdasarkan tabel di atas hasil uji statistik didapat $p$-value $=0,000$, yang berarti ada hubungan pendapatan dengan partisipasi suami dalam menjaga kesehatan kehamilan istri, Nilai OR didapat 6.981 yang dimaknai bahwa responden dengan pendapatan tinggi memiliki peluang 6.981 kali lebih besar berpartisipasi dalam menjaga kesehatan kehamilan istri dibandingkan responden dengan pendapatan rendah. 
Tabel 7. Hubungan Jumlah Anak dengan Partisipasi Suami dalam Menjaga Kesehatan Kehamilan

\begin{tabular}{|c|c|c|c|c|c|c|c|}
\hline \multirow{3}{*}{$\begin{array}{c}\text { Jumlah } \\
\text { anak }\end{array}$} & \multicolumn{4}{|c|}{ Partisipasi suami } & \multirow{3}{*}{$\mathrm{n}$} & \multirow{3}{*}{$\%$} & \multirow{3}{*}{$\begin{array}{c}p- \\
\text { value }\end{array}$} \\
\hline & \multicolumn{2}{|c|}{$\begin{array}{c}\text { Kurang } \\
\text { baik }\end{array}$} & \multicolumn{2}{|c|}{ Baik } & & & \\
\hline & $\mathbf{n}$ & $\%$ & $\mathbf{n}$ & $\%$ & & & \\
\hline$\geq 3$ & 22 & 79 & 6 & 21 & 28 & 100 & 0.261 \\
\hline$<3$ & 53 & 57 & 40 & 43 & 93 & 100 & \\
\hline Total & 75 & 62 & 46 & 38 & 121 & 100 & \\
\hline
\end{tabular}

Tabel 8. Hubungan Budaya dengan Partisipasi Suami dalam Menjaga Kesehatan Kehamilan

\begin{tabular}{|c|c|c|c|c|c|c|c|}
\hline \multirow{3}{*}{ Budaya } & \multicolumn{4}{|c|}{ Partisipasi suami } & \multirow{3}{*}{$\mathbf{n}$} & \multirow{3}{*}{$\%$} & \multirow{3}{*}{$\begin{array}{c}p- \\
\text { value }\end{array}$} \\
\hline & \multicolumn{2}{|c|}{$\begin{array}{c}\text { Kurang } \\
\text { baik }\end{array}$} & \multirow{2}{*}{\multicolumn{2}{|c|}{ Baik }} & & & \\
\hline & $\mathbf{n}$ & $\%$ & & & & & \\
\hline $\begin{array}{l}\text { Tidak } \\
\text { menerima }\end{array}$ & 53 & 66 & 27 & 34 & 80 & 100 & 0,349 \\
\hline Menerima & 22 & 54 & 19 & 46 & 41 & 100 & \\
\hline Total & 75 & 62 & 46 & 38 & 121 & 100 & \\
\hline
\end{tabular}

Berdasarkan tabel di atas hasil uji statistik didapat $p$-value $=0,349$, yang berarti tidak ada hubungan budaya dengan partisipasi suami dalam menjaga kesehatan kehamilan istri.

Tabel 9. Hubungan Dukungan Keluarga Dengan Partisipasi Suami Dalam Menjaga Kesehatan Kehamilan

\begin{tabular}{|c|c|c|c|c|c|c|c|}
\hline \multirow{3}{*}{$\begin{array}{c}\text { Dukungan } \\
\text { keluarga }\end{array}$} & \multicolumn{4}{|c|}{ Partisipasi suami } & \multirow{3}{*}{$\mathbf{n}$} & \multirow{3}{*}{$\%$} & \multirow{3}{*}{$\begin{array}{c}p- \\
\text { value }\end{array}$} \\
\hline & \multicolumn{2}{|c|}{$\begin{array}{c}\text { Kurang } \\
\text { baik }\end{array}$} & \multicolumn{2}{|c|}{ Baik } & & & \\
\hline & $\mathbf{n}$ & $\%$ & $\mathbf{n}$ & $\%$ & & & \\
\hline $\begin{array}{l}\text { Tidak } \\
\text { mendukung }\end{array}$ & 59 & 63 & 35 & 37 & 94 & 100 & 0,916 \\
\hline Mendukung & 16 & 59 & 11 & 41 & 27 & 100 & \\
\hline Total & 75 & 62 & 46 & 38 & 121 & 100 & \\
\hline
\end{tabular}

Berdasarkan tabel di atas hasil uji statistik didapat $p$-value $=0,916$, yang berarti tidak ada hubungan dukungan keluarga dengan partisipasi suami dalam menjaga kesehatan kehamilan istri.
Tabel 10. Hubungan Dukungan Petugas

Kesehatan Dengan Partisipasi

Suami Dalam Menjaga Kesehatan

Kehamilan

\begin{tabular}{|c|c|c|c|c|c|c|c|}
\hline \multirow{3}{*}{$\begin{array}{c}\text { Dukungan } \\
\text { petugas } \\
\text { kesehatan }\end{array}$} & \multicolumn{4}{|c|}{ Partisipasi suami } & \multirow{3}{*}{$\mathbf{n}$} & \multirow{3}{*}{$\%$} & \multirow{3}{*}{$\begin{array}{c}p- \\
\text { value }\end{array}$} \\
\hline & \multicolumn{2}{|c|}{$\begin{array}{c}\text { Kurang } \\
\text { baik }\end{array}$} & \multicolumn{2}{|c|}{ Baik } & & & \\
\hline & $\mathbf{n}$ & $\%$ & $\mathbf{n}$ & $\%$ & & & \\
\hline $\begin{array}{l}\text { Tidak } \\
\text { mendukung }\end{array}$ & 32 & 74 & 11 & 26 & 43 & 100 & 0,268 \\
\hline Mendukung & 43 & 55 & 35 & 45 & 78 & 100 & \\
\hline Total & 75 & 62 & 46 & 38 & 121 & 100 & \\
\hline
\end{tabular}

Berdasarkan tabel di atas hasil uji statistik didapat $p$-value $=0,268$, yang berarti tidak ada hubungan dukungan petugas kesehatan dengan partisipasi suami dalam menjaga kesehatan kehamilan istri.

Tabel 11. Hubungan Akses ke Pelayanan Dengan Partisipasi Suami Dalam Menjaga Kesehatan Kehamilan Partisipasi suami

\begin{tabular}{|c|c|c|c|c|c|c|c|}
\hline \multirow[t]{2}{*}{$\begin{array}{c}\text { Akses ke } \\
\text { pelayanan }\end{array}$} & \multicolumn{2}{|c|}{$\begin{array}{c}\text { Kurang } \\
\text { baik }\end{array}$} & \multicolumn{2}{|c|}{ Baik } & & \multirow[t]{2}{*}{$\%$} & \multirow{2}{*}{$\begin{array}{c}p- \\
\text { value }\end{array}$} \\
\hline & $\mathbf{n}$ & $\%$ & $\mathrm{n}$ & $\%$ & & & \\
\hline Jauh & 34 & 67 & 17 & 33 & 51 & 100 & 0,474 \\
\hline Dekat & 41 & 59 & 29 & 41 & 70 & 100 & \\
\hline Total & 75 & 62 & 46 & 38 & 121 & 100 & \\
\hline
\end{tabular}

Berdasarkan tabel di atas hasil uji statistik didapat $p$-value $=0,474$, yang berarti tidak ada hubungan akses kepelayanan dengan partisipasi suami dalam menjaga kesehatan kehamilan istri.

\section{ANALISIS MULTIVARIAT}

\begin{tabular}{|c|c|c|}
\hline Variabel & $p$-value & $\mathbf{O R}$ \\
\hline Sikap & 0.009 & 3.476 \\
\hline Pekerjaan & 0.014 & 4.255 \\
\hline Pendapatan & 0.000 & 7.142 \\
\hline
\end{tabular}

Berdasarkan tabel di atas menunjukkan variabel pendapatan merupakan variabel yang paling dominan berhubungan dengan partisipasi suami dalam menjaga kesehatan kehamilan, karena variabel pendapatan mempunyai nilai $p$ value paling kecil diantara variabel sikap dan pekerjaan yaitu dengan $p$-value $=0,000$. OR didapat 7.142 yang berarti responden yang memiliki pendapatan tinggi memiliki peluang 7.142 berpartisipasi dalam menjaga kesehatan kehamilan dibandingkan responden yang memiliki pendapatan rendah. 


\section{PEMBAHASAN}

\section{Hubungan Pengetahuan dengan Partisipasi Suami}

Hasil uji statistik didapat $p$-value $=0,002$ berarti ada hubungan pengetahuan dengan partisipasi suami dalam menjaga kesehatan kehamilan istri. Nilai OR didapat 3.688 yang dimaknai bahwa responden dengan pengetahuan baik memiliki peluang 3.688 kali lebih besar berpartisipasi dalam menjaga kesehatan kehamilan istri dibandingkan responden dengan pengetahuan kategori kurang baik.

Hasil ini didukung teori Notoatmodjo (2012) yang menyatakan faktor predisposisi yang berhubungan dengan perilaku adalah pengetahuan. Pengetahuan adalah merupakan hasil tahu dan terjadi setelah orang melakukan penginderaan terhadap suatu objek tertentu melalui penglihatan, pendengaran, penciuman, rasa, dan raba. Sebagian besar pengetahuan manusia diperoleh melalui mata dan telinga. Pengetahuan atau kognitif merupakan domain yang sangat penting dalam membentuk tindakan seseorang (overt behaviour).

Hasil ini sejalan dengan penelitian yang dilakukan oleh Suryati (2012) tentang hubungan tingkat pengetahuan suami dengan partisipasi suami terhadap kehamilan di Balai Pengobatan Sumber Sehat Marga Asih Kabupaten Bandung. Hasil uji chi square terdapat hubungan yang bermakna antara pengetahuan suami terhadap partisipasi terhadap kehamilan dengan $p$ value $=0,013$.

\section{Hubungan Sikap dengan Partisipasi Suami}

Hasil uji statistik didapat $p$-value $=0,030$, yang berarti ada hubungan yang signifikan antara sikap dengan partisipasi suami dalam menjaga kesehatan kehamilan istri. Nilai OR didapat 2.521 yang dimaknai bahwa responden dengan sikap kategori negatif memiliki peluang 2.521 kali lebih besar kurang berpartisipasi dalam menjaga kesehatan kehamilan istri dibandingkan responden dengan sikap positif.

Hasil ini didukung teori Notoatmojo (2012) yang menyatakan sikap merupakan faktor predisposisi faktor yang mempengaruhi perilaku kesehatan. Sikap adalah merupakan reaksi atau respon seseorang seseorang yang masih tertutup terhadap stimulus ataupun objek serta pandangan-pandangan atau perasaan yang disertai kecendrungan untuk bertindak sesuai objek tersebut.

Hasil ini sejalan dengan penelitian yang dilakukan oleh Bustami dkk (2012) tentang faktor-faktor yang berhubungan dengan partisipasi suami dalam menjaga kesehatan kehamilan istri di Puskesmas kota Bandar Lampung. Hasil penelitian diperoleh terdapat hubungan signifikan antara sikap $(p=0,000$, OR 5,77 ) dengan partisipasi suami dalam menjaga kesehatan kehamilan istri.

\section{Hubungan Tingkat Pendidikan dengan Partisipasi Suami}

Hasil uji statistik didapat $p$-value $=0,020$, yang berarti ada hubungan yang signifikan antara tingkat pendidikan dengan partisipasi suami dalam menjaga kesehatan kehamilan istri. Nilai OR didapat 2.815 yang dimaknai bahwa responden dengan pendidikan kategori rendah memiliki peluang 2.815 kali lebih besar kurang berpartisipasi dalam menjaga kesehatan kehamilan istri dibandingkan responden dengan pendidikan kategori tinggi.

Hasil ini didukung teori Notoatmodjo (2012) menyatakan individu dengan pendidikan formal yang lebih tinggi cenderung akan mempunyai pengetahuan yang lebih tinggi dibandingkan dengan individu yang memiliki tingkat pendidikan formal yang lebih rendah, karena akan lebih mampu dan mudah memahami arti dan pentingnya kesehatan dan gangguangangguan kesehatan yang mungkin terjadi. Pengetahuan akan mempengaruhi pola fikir seseorang, selain itu kemampuan kognitif membentuk cara fikir seseorang, meliputi kemampuan untuk mengerti faktor-faktor yang berpengaruh dalam kondisi sakit dan untuk menerapkan pengetahuan tentang sehat dan sakit dalam praktek kesehatan personal, informasi baru dan penerimaan konsep baru.

Hasil ini sejalan dengan penelitian yang dilakukan oleh Bustami (2012) tentang faktorfaktor yang berhubungan dengan partisipasi suami dalam menjaga kesehatan kehamilan istri di Puskesmas kota Bandar Lampung. Hasil penelitian diperoleh terdapat hubungan signifikan antara tingkat pendidikan $(p=0,020$, OR 2,7$)$ dengan partisipasi suami dalam menjaga kesehatan kehamilan istri.

\section{Hubungan Pekerjaan dengan Partisipasi Suami}

Hasil uji statistik didapat $p$-value $=0,007$, yang berarti ada hubungan yang signifikan antara pekerjaan dengan partisipasi suami dalam menjaga kesehatan kehamilan istri. Nilai OR didapat 4.351 yang dimaknai bahwa responden yang bekerja memiliki peluang 4.351 kali lebih besar kurang berpartisipasi dalam menjaga kesehatan kehamilan istri dibandingkan responden yang tidak bekerja. Karena suami yang 
bekerja cenderung sibuk dengan pekerjaannya dan tidak sempat mengantarkan isterinya ke fasilitas kesehatan untuk memeriksakan kehamilan.

Hasil ini didukung teori Notoatmojo (2012) yang menyatakan Tingkat kesejahteraan keluarga dipengaruhi oleh status pekerjaan dan besarnya pendapatan suami yang berkerja. Sumber pendapatan yang dimaksud adalah setiap aktifitas usaha atau bukan usaha yang memberi penerimaan keuangan bagi rumah tangga. Besarnya pendapatan erat hubungannya dengan status pekerjaan seorang suami dan mempengaruhi peran suami dalam perawatan kesehatan kesehatan ibu hamil.

Hasil ini sejalan dengan penelitian yang dilakukan oleh Septyaningrum (2015) tentang hubungan status pekerjaan suami dengan peran suami selama perawatan kehamilan istri di Puskesmas Baki Sukoharjo, hasil uji chi square didapat nilai $p$-value $=0,004$ yang berarti hubungan status pekerjaan suami dengan peran suami selama perawatan kehamilan istri.

\section{Hubungan Pendapatan dengan Partisipasi Suami}

Hasil uji statistik didapat $p$-value $=0,000$, yang berarti ada hubungan yang signifikan antara pendapatan dengan partisipasi suami dalam menjaga kesehatan kehamilan istri. Nilai OR didapat 6.981 yang dimaknai bahwa responden dengan pendapatan rendah memiliki peluang 6.981 kali lebih besar kurang berpartisipasi dalam menjaga kesehatan kehamilan istri dibandingkan responden dengan pendapatan tinggi.

Hasil ini sejalan dengan penelitian yang dilakukan oleh Bustami dkk (2012) tentang faktor-faktor yang berhubungan dengan partisipasi suami dalam menjaga kesehatan kehamilan istri di Puskesmas kota Bandar Lampung. Hasil penelitian diperoleh terdapat hubungan signifikan antara pendapatan ( $p=$ 0,001 , OR 4,1) dengan partisipasi suami dalam menjaga kesehatan kehamilan istri.

\section{Hubungan Jumlah Anak dengan Partisipasi Suami}

Hasil uji statistik didapat $p$-value $=0.261$, yang berarti tidak ada hubungan yang signifikan antara jumlah anak dengan partisipasi suami dalam menjaga kesehatan kehamilan istri.

Hasil ini tidak sejalan dengan teori Manuaba (2010) yang menyatakan jumlah anak $<3$ akan lebih meningkatkan partisipasi suami dalam menjaga kesehatan kehamilan istri sedangkan jumlah anak $\geq 3$ akan melemahkan partisipasi suami dalam menjaga kesehatan kehamilan istri karena beranggapan semakin sering melahirkan maka ibu sudah memiliki pengalaman sehingga suami tidak perlu ikut berpartisipasi.

Hasil ini sejalan dengan penelitian yang dilakukan oleh Bustami dkk (2012) tentang faktor-faktor yang berhubungan dengan partisipasi suami dalam menjaga kesehatan kehamilan istri di Puskesmas kota Bandar Lampung. Hasil penelitian diperoleh tidak terdapat hubungan signifikan antara jumlah anak $(p=0,277)$ dengan partisipasi suami dalam menjaga kesehatan kehamilan istri.

\section{Hubungan Budaya dengan Partisipasi Suami}

Hasil uji statistik didapat $p$-value $=0,349$, yang berarti tidak ada hubungan antara budaya dengan partisipasi suami dalam menjaga kesehatan kehamilan istri.

Hasil ini tidak sejalan dengan teori Bobak (2005), faktor sosial budaya yang berpengaruh dalam pertisipasi keluarga dalam perlindungan kesehatan reproduksi ibu hamil adalah anggapan bahwa kehamilan dan persalinan adalah urusan perempuan dan kaum ibu.

Hasil ini tidak sejalan dengan penelitian yang dilakukan oleh Bustami dkk (2012) tentang faktor-faktor yang berhubungan dengan partisipasi suami dalam menjaga kesehatan kehamilan istri di Puskesmas kota Bandar Lampung. Hasil penelitian diperoleh terdapat hubungan signifikan antara budaya $(p=0,000$, OR $4,17)$ dengan partisipasi suami dalam menjaga kesehatan kehamilan istri.

\section{Hubungan Dukungan Keluarga dengan Partisipasi Suami}

Hasil uji statistik didapat $p$-value $=0,916$, yang berarti tidak ada hubungan yang signifikan antara dukungan keluarga dengan partisipasi suami dalam menjaga kesehatan kehamilan istri.

Hasil ini didukung teori Rogers (1978) dalam Notoatmodjo (2012) yang menyatakan dukungan keluarga bukan lah satu-satunya faktor yang mempengaruhi perilaku kesehatan seseorang. Banyak faktor yang mempengaruhi perilaku kesehatan seseorang diantaranya pengetahuan dan sikap.

Hasil ini tidak sejalan dengan penelitian yang dilakukan oleh Bustami dkk (2012) tentang faktor-faktor yang berhubungan dengan partisipasi suami dalam menjaga kesehatan kehamilan istri di Puskesmas kota Bandar Lampung. Hasil penelitian diperoleh terdapat hubungan signifikan antara dukungan keluarga ( $p$-value $=0,007$, OR 6,4) dengan partisipasi suami dalam menjaga kesehatan kehamilan istri. 


\section{Hubungan Dukungan Petugas Kesehatan dengan Partisipasi Suami}

Hasil uji statistik didapat $p$-value $=0,268$, yang berarti tidak ada hubungan dukungan petugas kesehatan dengan partisipasi suami dalam menjaga kesehatan kehamilan istri.

Hasil ini tidak sejalan dengan teori Notoatmodjo (2012) yang menyatakan dukungan petugas kesehatan merupakan faktor penguat (reinforcing) yang mempengaruhi perilaku. Dukungan petugas kesehatan adalah, respon yang diberikan petugas kesehatan terhadap klien. Sikap yang baik dari petugas kesehatan akan mempengaruhi klien dalam mengikuti anjuran yang diberikan oleh petugas kesehatan dalam pemberian pelayanan kesehatan.

Hasil ini tidak sejalan dengan penelitian yang dilakukan oleh Bustami dkk (2012) tentang faktor-faktor yang berhubungan dengan partisipasi suami dalam menjaga kesehatan kehamilan istri di Puskesmas kota Bandar Lampung. Hasil penelitian diperoleh terdapat hubungan signifikan antara dukungan petugas kesehatan ( $p=0,004$, OR 3,5) dengan partisipasi suami dalam menjaga kesehatan kehamilan istri.

\section{Hubungan Akses Kepelayanan dengan Partisipasi Suami}

Hasil uji statistik didapat $p$-value $=0,474$, yang berarti tidak ada hubungan akses kepelayanan dengan partisipasi suami dalam menjaga kesehatan kehamilan istri. Hasil ini tidak sejalan dengan teori Manuaba (2010) yang menyatakan yang menyatakan akses kesehatan merupakan determinan yang sering menjadi alasan utama masyarakat jarang memanfaatkan penyedia fasilitas jasa pelayanan kesehatan. Jarak yang cukup jauh $>1 \mathrm{~km}$ dari pusat pelayanan kesehatan merupakan determinan yang mempengaruhi kecenderungan masyarakat untuk tidak memanfaatkan penyedia fasilitas jasa pelayanan kesehatan.

Hasil ini sejalan dengan penelitian Djannah dan Wardani (2010) tentang faktorfaktor yang berhubungan dengan partisipasi suami dalam merawat kehamilan istri di wilayah kerja Puskesmas Kedung Wetan Yogyakarta, hasil penelitian didapat tidak ada hubungan akses kepelayanan kesehatan dengan partisipasi suami dalam merawat kehamilan istri ( $p$-value $=0,343)$.

\section{Analisis Multivariat}

Hasil penelitian variabel yang paling dominan berhubungan dengan partisipasi suami dalam menjaga kesehatan kehamilan adalah variavel pendapatan tinggi dengan $p$ value $=0,000$. OR didapat 7.142 yang berarti responden yang memiliki pendapatan tinggi memiliki peluang 7.142 lebih besar partisipasi suami dalam menjaga kesehatan kehamilan dibandingkan responden dengan responden yang memiliki pendapatan rendah. Hasil ini didukung teori Roger (2014) yang menyatakan pada masyarakat kebanyakan, 75-100\% penghasilannya dipergunakan untuk membiayai keperluan hidupnya, sehingga pada akhirnya ibu hamil tidak diperiksakan ke pelayanan kesehatan karena tidak mempunyai kemampuan untuk membayar. Atas dasar faktor tersebuat diatas maka prioritas kegiatas GSI ditingkat keluarga dalam perberdayaan suami tidak hanya terbatas pada kegiatan yang bersifat anjuran sajaseperti selama ini. Akan tetapi lebih bersifat holistic. Secara konkrit dapat ditemukan bahwa pemberdayaan ekonomi keluarga sehingga kepala keluarga tidak mempunyai alasan untuk tidak memperhatikan kesehatan isterinya karena permasalahan keuangan Hasil ini sejalan dengan penelitian yang dilakukan oleh Djannah dan Wardani (2010) tentang faktor-faktor yang berhubungan dengan partisipasi suami dalam merawat kehamilan istri di wilayah kerja Puskesmas Kedung Wetan Yogyakarta, hasil uji regresi logistik berganda didapat variabel yang paling dominan berhubungan dengan partisipasi suami dalam merawat kehamilan istri adalah status pekerjaan $(p$-value $=0,010)$.

\section{SIMPULAN}

1. Partisipasi suami dalam menjaga kesehatan kehamilan istri lebih tinggi pada kategori kurang berpartisipasi sebesar 62\%, pengetahuan suami tentang dalam menjaga kesehatan kehamilan istri lebih tinggi pada kategori kurang berpartisipasi sebesar 68\%, sikap suami dalam menjaga kesehatan kehamilan istri lebih tinggi pada kategori kurang negatif sebesar $65 \%$, tingkat pendidikan suami lebih tinggi pada kategori rendah sebesar $72 \%$, pekerjaan suami lebih tinggi pada kategori bekerja sebesar $74 \%$, pendapatan suami lebih tinggi pada kategori rendah sebesar 56\%, jumlah anak lebih tinggi pada kategori $<3$ sebesar $77 \%$, budaya lebih tinggi pada kategori tidak menerima sebesar 66\%, dukungan keluarga lebih tinggi pada kategori tidak mendukung sebesar $78 \%$, dukungan petugas kesehatan lebih tinggi pada kategori mendukung sebesar $64.5 \%$. Akses kepelayanan lebih tinggi pada kategori dekat sebesar 58\%. 
2. Terdapat hubungan pengetahuan dengan partisipasi suami dalam menjaga kesehatan kehamilan istri ( $p$-value $=0,002) \mathrm{OR}=3.688$.

3. Terdapat hubungan sikap dengan partisipasi suami dalam menjaga kesehatan kehamilan istri $(p$-value $=0,030) \mathrm{OR}=2.521$.

4. Terdapat hubungan tingkat pendidikan dengan partisipasi suami dalam menjaga kesehatan kehamilan istri ( $p$-value $=0,020)$ $\mathrm{OR}=2.815$.

5. Terdapat hubungan pekerjaan dengan partisipasi suami dalam menjaga kesehatan kehamilan istri $(p$-value $=0,007) \mathrm{OR}=4.351$.

6. Terdapat hubungan pendapatan dengan partisipasi suami dalam menjaga kesehatan kehamilan istri $(p$-value $=0,000) \mathrm{OR}=6.981$.

7. Tidak ada hubungan yang signifikan antara jumlah anak dengan partisipasi suami dalam menjaga kesehatan kehamilan istri ( $p$ value $=0,261$ ).

8. Tidak ada hubungan yang signifikan antara budaya dengan partisipasi suami dalam menjaga kesehatan kehamilan ( $p$ value $=0,349$ ). Tidak ada hubungan yang signifikan antara dukungan keluarga dengan partisipasi suami dalam menjaga kesehatan kehamilan istri $(p$-value $=0,916)$.

9. Tidak ada hubungan yang signifikan antara dukungan petugas kesehatan dengan partisipasi suami dalam menjaga kesehatan kehamilan istri $(p$-value $=0,268)$.

10. Tidak ada hubungan yang signifikan antara akses kepelayanan dengan partisipasi suami dalam menjaga kesehatan kehamilan istri ( $p$ value $=0,474$ ).

\section{DAFTAR PUSTAKA}

Bustami. 2012. Faktor-faktor yang Berhubungan dengan Partisipasi Suami dalam Menjaga Kesehatan Kehamilan Istri di Puskesmas Kota Bandar Lampung.

BKKBN. 2008. Keluarga Berencana, Kesehatan Reproduksi, Gender dan Pembangunan Kependudukan. Deputi Keluarga Sejahtera dan Pemberdayaan Perempuan. Jakarta.

Bobak, Lowdermilk and Jensen. 2005. Buku Ajar Keperawatan.

Dinas Kesehatan Provinsi Lampung. 2014. Profil Bandar Lampung.

Djannah dan Wardani. 2010. Faktor-faktor yang Berhubungan dengan Partisipasi Suami dalam Merawat Kehamilan Istri di wilayah Kerja Puskesmas Kedung Wetan Yogyakarta.
11. Variabel pendapatan merupakan variabel yang paling dominan berhubungan dengan partisipasi suami dalam menjaga kesehatan kehamilan istri $(p$-value $=0,000) \mathrm{OR}=7.142$.

\section{SARAN}

1. Diharapkan petugas kesehatan dapat mensosialisasikan program Penerima Bantuan Iuran (PBI) BPJS kepada suami khususnya yang memiliki pendapatan rendah agar memanfaatkan program tersebut untuk mendapatkan pembiayaan gratis yang ditanggung oleh pemerintah termasuk didalamnya biaya pemeriksaan kehamilan, pengobatan dasar di fasilitas tingkat 1 Puskesmas serta biaya persalinan.

2. Meningkatkan upaya sosialisasi partisipasi suami dalam menjaga kesehatan kehamilan istri melalui penyuluhan yang dilakukan setiap bulan dengan menggunakan bahasa yang mudah difahami dan menggunakan media promosi yang menarik seperti leaflet, poster dan brosur.

3. Mensosialisasikan kepada suami khususnya dengan pendapatan rendah jenis - jenis makanan yang dibutuhkan oleh ibu hamil selama kehamilan melalui demosntrasi secara langsung untuk memudahkan suami memahami materi yang disampaikan sehingga dapat diaplikasikan suami untuk memanfaatkan bahan makanan yang tidak perlu mahal akan tetapi kaya dengan nilai gizi yang tinggi untuk memenuhi kebutuhan gizi ibu selama kehamilan.

Hastono. 2007. Analisa Data. Jakarta: FKMUI. Manuaba, Ida Bagus Gede. 2010. Ilmu Penyakit, Penyakit Kandungan dan Keluarga Berencana. Jakarta: EGC.

Mahlida. 2012. Hubungan Dukungan Suami terhadap Tingkat Kepatuhan Pemeriksaan Kehamilan di Puskesmas Simo Mulyo Surabaya.

Notoatmodjo, Soekidjo. 2012. Pendidikan dan Perilaku Kesehatan. Jakarta: Rineka Cipta.

Notoatmodjo, Soekidjo. 2010. Metodologi Penelitian Kesehatan. Jakarta: Rineka Cipta.

Roger. 2014. Faktor Faktor Yang Mempengaruhi Perilaku Kesehatan. Jakarta: Gramedia.

Suryati. 2012. Hubungan Tingkat Pengetahuan Suami dengan Partisipasi Suami terhadap 
Kehamilan di Balai Pengobatan Sumber Sehat Marga Asih Kabupaten Bandung. Septyaningrum. 2015. Hubungan Status Pekerjaan Suami dengan Peran Suami selama Perawatan Kehamilan Istri di Puskesmas Baki Sukoharjo.

Wijayarni, Maria A., Peter I. Anugrah. 2005. Maternitas. Jakarta: EGC. 